\title{
Élet egy kisváros peremén
}

\section{Living at the edge of a small town}

\author{
FEHÉR KATALIN, VIRÁG TÜNDE
}

FEHÉR Katalin: tudományos segédmunkatárs, MTA Közgazdaság- és Regionális Tudományi Kutatóközpont, Regionális Kutatások Intézete, Budapest; feher@rkk.hu VIRÁG Tünde: tudományos fömunkatárs, MTA Közgazdaság- és Regionális Tudományi Kutatóközpont, Regionális Kutatások Intézete, Budapest; viragt@rkk.hu

KULCSSZAVAK: lakhatás, szociális bérlakás, térbeli és társadalmi egyenlőtlenségek, kirekesztés, társadalmi kapcsolatok, Alföld

ABSZTRAKT: A folyamatosan változó, városvezetés és városlakók által képzett elkülönült terek térbeli különállásukkal a társadalmi távolságokat is leképezik. A kutatásunk terepéül szolgáló alföldi kisváros három bérlakástömbje közül a legalacsonyabb státuszú, 14 lakásos telep története a hajdani előkelő tiszti telepi múlttól a cigány gettóvá válásig ível. Abban, hogy a város e szociálisbérlakás-tömbje napjainkra nemcsak térben, hanem társadalmilag is peremhelyzetbe került, egyfelől a városban zajló telepfelszámolások és az ehhez köthető költöztetések, a város bérlakás-politikája és a szelektív lakáskiutalási rendszer, másfelől a marginalizálódó tömbben elinduló szelekciós folyamatok egyaránt szerepet játszottak. A többségi társadalom szemében társadalmilag és etnikailag homogénnek tűnő, a város lakói és intézményei által stigmatizált tömbben élők gazdasági stabilitását és boldogulási mintáit vizsgálva az itt élő családok rendkívül heterogén képet mutatnak. A legalább egy állandó keresettel rendelkező, gazdaságilag viszonylag stabilnak tekinthető családoktól a billenékeny anyagi helyzetűeken át az eladósodott, máról holnapra élő kilakoltatásra várókig sokféle helyzetben élő családot találunk. A hosszú évek, évtizedek óta egymás mellett élő családok között szoros, gyakran rokoni kapcsolatok szövődtek, amelyek segítik a mindennapi túlélést, de be is zárják a családokat e kapcsolatrendszerbe.

Katalin FEHÉR: junior research fellow, Institute for Regional Studies, Centre for Economic and Regional Studies, Hungarian Academy of Sciences, Budapest; feher@rkk.hu

Tünde VIRÁG: senior research fellow, Institute for Regional Studies, Centre for Economic and Regional Studies, Hungarian Academy of Sciences, Budapest; viragt@rkk.hu

KEYWORDS: housing, public social housing, spatial and social inequalities, exclusion, social relations, Great Plain

ABSTRACT: Municipal governments and citizens continually shape and differentiate spaces. These spaces map social distances by their spatial isolation. Out of the three social housing blocks in a small town of the Great Plain, the lowest-status settlement's history encompasses a former distinguished officers' residence that turned into a Roma ghetto. Several factors played equally important roles in taking the social housing estate to a position on the edge, not only spatially

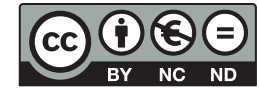


but also socially: On the one hand, it was the demolition of the former settlements and the ensuing enforced mobility, the housing policy of the town and the unequal allocation of social housing units, on the other hand, it was the selection processes evolving in the marginalised block.

In the eyes of the majority, the population of the settlement seems socially and ethnically homogenous and it is uniformly stigmatised by the local institutions and the other inhabitants. Analysing both financial stability and survival strategies of the block's residents, we have found that families living there show rather large differences in this respect, and that they constitute a heterogeneous population.

The settlement comprises people living in differing socio-economic conditions; one circle of families lives in a relatively stable situation with steady incomes, another is in unstable, uncertain circumstances, while there are indebted families living from one day to another and expecting their eviction from their tenement any time. Tenants identified with relatively stable backgrounds are both the ones that moved in first into the social housing block and the well embedded families who are gaining stability through their personal social networks. Whereas the situation of newcomers - those who recently moved in from predominantly lower-status areas of the town, temporary family shelters or from farm buildings in the outer areas - is the most unstable. However, even those families with the most stable financial background cannot afford to buy an independent home or rent a flat on the private market. Spatial and, consequently, social mobility is almost impossible for those occupants.

Between families having lived side by side for years and decades, tight, sometimes familial relations are woven. These relations help in everyday survival but also keep those families isolated in their inner - hermetic - social network. In parallel with the marginalisation of the settlement, the binding connections that can advance the survival of these families became more and more important while linkages toward other social groups and the majority institutions that could foster spatial and social mobility are lost.

\section{Bevezető}

A térbeli kirekesztés, a szegregáció különböző formáinak és azok változásának kutatása a magyar szociológiában szorosan összekapcsolódik a romák egy-egy településen belüli térbeli elhelyezkedésének, a cigánytelepek felszámolásának és a szegregáció új formái kialakulásának problémakörével. A szocializmus időszakából a hatósági felméréseken túl elsősorban a Kemény István vezetésével folyó kutatásokból rendelkezünk erre vonatkozó adatokkal. Az 1971-es kutatás tapasztalatai szerint a cigány népesség kétharmada szegregált körülmények között, jellemzően hagyományos telepeken, a települések szélén vagy külterületen, de minden esetben a falvaktól elszigetelten élt (Kemény 1976). Az 1993-ban megismételt felmérés idejére az elkülönülés nagymértékben visszaszorult, majd a 2003-as felvétel eredményei ismét az 1971-es arányokat mutatják; az ezredfordulóra a cigány népesség kétharmada többségében cigányok lakta településrészeken élt. Mindeközben megváltoztak a térbeli kirekesztés formái: míg a hatvanas években a cigány családok többsége a településeken kívül elhelyezkedő telepeken élt, a nyolcvanas évekre megjelentek az „elcigányosodó” aprófalvak (Havas 1999; Ladányi, Szelényi 2004), a városi romák pedig többnyire alacsony státuszú, leromló, slumosodó lakónegyedekbe tömörültek (Ambrus 1988; Ladányi 1989; Solt 1998). Az ezredfordu- 
lót követően a periferikus vidéki terekben megindult a gettósodó aprófalvak térséggé szerveződése (Virág 2006), míg a városokban elsősorban a városrehabilitációs programok indukáltak olyan dzsentrifikációs folyamatokat (Nagy, Timár 2007), amelyek a települési önkormányzatoknak a többségi társadalom által támogatott elkülönítési törekvéseit tükrözik (Janky, Kemény 2004; Ladányi 2000). A Nemzeti Fejlesztési Ügynökség kezdeményezésére készült kérdőíves felmérés eredményei szerint az országban összesen másfél ezer szegény- és cigánytelep, szegregátum található (Domokos, Herczeg 2010). A kétezres évek első felében készült adatfelvételek a (városi slumokban, telepeken, gettósodó falvakban) kizárólag vagy túlnyomórészt roma szomszédok között élők arányát 45-55\%-ra becsülték (Teller 2011). A romák lakóhelyi szegregációjának országos növekedéséhez jelentősen hozzájárul az intézményi diszkrimináció is, amely a lakhatási integrációs programok helyi fogadtatásában, megvalósításában is megmutatkozik (Berescu, Petrović, Teller 2013; Éves jelentés a lakhatási szegénységről 2011; Teller 2011). Ugyanakkor fontos megjegyeznünk, hogy a módszertani különbségek, valamint a „cigánytelep” fogalmának eltérő értelmezései okán a különféle adatforrások nehezen összevethetők.

Míg a szociológiai adatfelvételek többsége a térbeli elkülönülés formáira és mértékére fókuszál, addig az antropológiai kutatások a városok térbeli-társadalmi átalakulásának vizsgálatakor arra hívják fel a figyelmet, hogy a gettó vagy cigánytelep fogalmának körültekintés nélküli használata általánosításhoz, sztereotípiák kialakulásához, megerősödéséhez vezet. Az antropológusok a hangsúlyt a statisztikai adatok szintjén társadalmilag és gazdaságilag homogénnek tűnő terek heterogenitásának, belső differenciáltságának vizsgálatára helyezik (Small 2008; Virág 2008), hasonlóképpen különbséget tesznek az etnikai koncentráció és kirekesztés között. Ennek megfelelően térbeli-társadalmi kirekesztésről akkor beszélhetünk, ha az etnikai koncentráció az alacsony státuszú, iskolázatlan munkanélküli családok, azaz a szegénység koncentrációjával jár együtt, valamint ha a többségi társadalom az adott teret és az ott élő embereket egyaránt stigmatizálja (Wacquant 2007). Egy-egy településen belül e marginalizált, stigmatizált területek státusza nem állandó, hanem dinamikusan változik, tehát tükrözi a várospolitikát formáló vezetők, a városi lakosok szegényekhez, más etnikai csoportokhoz való viszonyát. Azaz a városlakók és a városvezetés által kialakított elkülönült (alacsony vagy magas státuszú) terek, illetve a megjelölésükre használt fogalmak nem önmagukban létező, állandó, objektív kategóriák, hanem a gazdasági, társadalmi környezet hatására folyamatosan változnak.

A tanulmányunk terepéül ${ }^{1}$ szolgáló alföldi kisvárosban nagy számban, bár a teljes népességhez viszonyítva mindössze körülbelül 10\%-os arányban van jelen a cigány népesség, akik a szegénységben élők jelentős részét alkotják. Ahogy szinte minden magyarországi településen, úgy kutatásunk helyszínén is a szegény, többségében cigány családok városon belüli térbeli elhelyezkedését a mai napig meghatározza, hogy a hatvanas-hetvenes években volt-e a településen 
belül vagy mellette nagyobb cigánytelep, valamint az, hogy a telepet az adott tanács milyen koncepció szerint igyekezett felszámolni (Berey 1990; Lengyel 2006). Kutatási terepünkön a település mellett elhelyezked” hatalmas „cigányváros" lakóit a városvezetés tudatosan különböző területekre, de a város szélén, általában a kivezető utak mellett épített cs-házakba ${ }^{2}$ költöztette. Az új városszéli utcák viszonylag gyorsan újratermelték a telepi viszonyokat, hiszen az első beköltözők gyermekei többnyire nem tudtak önálló háztartást alapítani, illetve elköltözni, így maradtak a családi házban vagy az a mellé felhúzott melléképületben, tovább növelve a telep zsúfoltságát, erősítve a szegénység koncentrációját.

A városokban kialakuló szegregátumok újratermelődését nagyban befolyásolta a '90-es évek lakásprivatizációja. Az önkormányzati bérlakások aránya 22\%-ról 4\%-ra csökkent 1994-re, és azóta is mérséklődik, míg a magántulajdonú bérlakások aránya mindössze 4\%, ami töredéke az Európai Unió országaiban jellemző aránynak (Hegedüs, Eszenyi, Somogyi, Teller 2009; Hegedüs, Tosics 1998). A bérlakások csekély száma miatt beszűkült a szociális lakáspolitika hagyományos lakásbázisa (önkormányzati bérlakások) és nem alakult ki átfogó, a lakhatás biztonságát garantáló, szociál- és lakáspolitikai elemeket ötvöző rendszer.

A vizsgált alföldi kisváros szociálisbérlakás-politikáját az jellemzi, hogy eltérő státuszú, a város különböző részein elhelyezkedő lakásokat tart fenn és pontosan szabályozza a különböző társadalmi státuszú családok lakásokhoz való hozzáférését. A városban az elszórtan elhelyezkedő bérlakásokon kívül három szociálisbérlakás-tömb található. Az első tömb társasházi környezetben áll, ma elsősorban az elszegényedő középosztály számára nyújt otthont. A második tömb egy nővérszállóból kialakított, apró lakásokból álló épület, ahol a szobaméretnek megfelelően egyedülálló, nyugdíjas vagy rokkantnyugdíjas emberek laknak nagy arányban. A harmadik tömb egy ipari területbe ékelődött, egykori katonai tiszti lakásokból kialakított, mára leromlott, rendkívül rossz hírü tömb, amelyet a városban stigmatizált térként, cigánytelepként, veszélyes helyként tartanak számon (Fehér, Müller, Tabajdi 2013).

Tanulmányunk e harmadik szociálisbérlakás-tömb történetén és a jelenleg itt élő családok élettörténeti elbeszélésein keresztül mutatja be, hogyan alakult át a háztömb szociális és etnikai összetétele, és hogy e változások hogyan hatottak a tömb megítélésére az elmúlt évtizedekben. A napjainkban itt élő családok demográfiai összetételének, boldogulási lehetőségeinek elemzésével feltárjuk, hogy a város és a városlakók által stigmatizált, roma gettóként számon tartott telepen belül milyen különbségek fedezhetők fel a családok között, hogyan differenciálódik a telep mikrotársadalma, hogyan alakulnak és milyen jelentőséggel és funkcióval bírnak a telepen belül működtetett, valamint a telepről kifelé mutató társadalmi kapcsolatok. 


\section{Tiszti házból roma gettó - a telep története}

Az alföldi kisváros Marosi út néven elhíresült szociálisbérlakás-tömbje a város északi részén található, az egykori szovjet laktanyaépületek egy részéből lett kialakítva. A háztömböt alkotó 14 lakás - egy kivétellel - egy épületben található: a fóúttal párhuzamosan, hosszan elnyúló, rendkívül rossz állapotú épület egymás mellett elhelyezkedő színesre festett lakrészeit kis kertek keretezik. Ezek néhol lomok tárolásra szolgálnak vagy padnak adnak helyet, máshol kis kertet gondoznak a lakók, bár a virágok sem javítanak az épület rendezetlen, kaotikus összképén. A tömb közepén két emeletes lakás töri meg a földszintes sort: a mindig nyitva álló ajtóból sötét, dohos lépcsőház nyílik, amelynek hiányos ablakaiból szemek lesik az udvar történéseit. Egyetlen különálló lakás helyezkedik el az épület mögött, ahol az átlagosnál kisebb alapterületü építményt különböző lakrészekkel, házilag toldották meg. Itt, a házsor mögött kamrák is állnak, legtöbbjükön hiányzik az ajtó. A telepen relatíve nagy, $70 \mathrm{~m}^{2}$ körüli lakások találhatók, bennük szoba, konyha, fürdőszoba és kamra, ebből következően általában nagyobb, gyerekes családok költözhettek ide. A telep mindennapjaira jellemző, hogy sokan járnak át egymáshoz egyik lakásból a másikba vagy ülnek ki a közös udvarként funkcionáló téren elhelyezett traktorgumira, szőnyegre vagy padra.

A bérlakástömb nem volt mindig ilyen állapotban. A szocializmus időszakában a Marosi úti épületsor a városban állomásozó szovjet hadsereg tisztjeinek nyújtott otthont, majd a feleslegessé váló tiszti lakások egy részét a város a '80-as évek elejétől önkormányzati bérlakásokká alakította át. A telepen élő családok átalakuló, változó társadalmi-etnikai összetételét, ezzel párhuzamosan a tömb változó státuszát, megítélését az itt élő családokkal készült élettörténeti interjúkból tudjuk rekonstruálni. A telepre még a rendszerváltás előtt beköltöző lakók különösen szerencsésnek érezték magukat, hiszen a tágas lakások és az udvar kellemes, falusias környezetet nyújtottak. Többen faluról vagy tanyáról származtak, idegenkedtek az emeletes házaktól. Ebben az időben a lakók - az önkormányzat hallgatólagos támogatásával - a házsor mögött futó üres területet felszántották, így tettek szert egy kis veteményesre, de akadt, aki a kertművelés mellett állattartással is kiegészítette jövedelmét. Az idillt sugárzó visszaemlékezések szerint a hely ekkor még őrizte a tiszti lakások méltóságát: napközben csend volt, az udvar rendezett, minden lakó dolgozott, a gyerekek pedig iskolába jártak. Hétvégén a szomszédok kiültek az udvarba vagy a pázsiton napoztak.

A rendszerváltás előtt beköltöző négy család és leszármazottaik a 14 lakásból ma ötöt foglalnak el. Az egyikben a telep egyetlen nem cigány származású lakója él, a többit cigány-nem cigány vegyes házasságban élő családok lakják. Utóbbi négy háztartásra jellemző, hogy mindkét szülő, ha nagyon alacsony beosztásban is, de folyamatosan dolgozott, a cigány férjek egyike a város egyik elismert éttermi zenésze volt. E családok között a gyerekek házassága révén viszonylag gyorsan rokoni kapcsolatok szövődtek; van, aki már elköltözött a te- 
lepről, és van, aki jelenleg is itt él. Fontos rögzítenünk, hogy a kilencvenes évek elején itt felnövő gyerekek - ha kisebb kitérővel is - de szívesen tértek vissza a telepre, gyakran más lakáson minőségi cserével túladva vagy lakásigénylést kijárva költöztek ide. A rendszerváltás előtt ideköltözött és jelenleg is itt élő családok mindegyike egészen a közelmúltig rendszeres jövedelemmel rendelkezett, a most is állandó munkahellyel rendelkező kevesek közé tartozik vagy saját jogú nyugdíjat kap.

Napjainkban a nyolcvanas években ideköltözött, a múltra idillként emlékezők jószerivel mindegyike elköltözne, ha adódna erre lehetősége: „Mondanák, hogy máma kell pakolni, vagy holnap, lehet, nem fájna a fejem." A kilencvenes évek végén kezdődő és a telep „leromlásához” kötődő időszakban beköltöző családoknak már nem kiváltságot jelentett a Marosi úti lakás, hanem egy probléma szükségszerű, kényszerű megoldását. Az utóbb érkező családok most is rosszabb helyzetben vannak, közülük kerülnek ki azok, akiket a kutatás évének nyarán kilakoltatás fenyegetett. Az ezredfordulótól a beköltöző családok a város különböző szegregált telepeiről érkeztek. 1997-ben és 2001-ben két család is érkezett a szomszédos cs-lakásos telepről. Ugyancsak két család jött ide a lakhatási zsákutcának bizonyuló keleti tömbből, ahova a város eleve a problémásnak tekintett, fizetési gondokkal küszködő lakókat költöztette, s amelyet majd egy évtized után, annak teljes leromlásával és kriminalizálódásával kénytelen volt felszámolni. Egy-egy család pedig külterületi tanyáról, illetve a déli városrész cigányok lakta utcájából került ide. Az utóbbi években ideköltöző családok korábbi életszakaszaiban jelentős szerepet játszott a családok átmeneti otthona, ahol hosszabb-rövidebb időre meghúzhatták magukat; a kisgyerekes generáció ki tudott költözni az otthonba, ám sok esetben az egy-másfél év különélés után ugyanoda, ugyanazon körülmények közé voltak kénytelenek visszaköltözni. Ezek a családok mindig egyazon utcák, intézmények rendszerében bolyonganak, számukra a Marosi úti telep a biztos lakhatás lehetőségét jelenti (Fehér, Müller, Tabajdi 2013).

A kilencvenes évek végétől a telep egyre marginalizáltabb lett, az egyértelműen romló helyzetet a jelenlegi lakók az utóbbi években beköltöző, alacsony társadalmi státuszú családokhoz kapcsolják. A változást elsősorban a szemetesebb, koszosabb környezethez kötik, ám az a személyes kapcsolatokat is érinti: sokan panaszkodnak a zavaró hangoskodásra, a hétvégi „magnózásra”, a kisgyerekekkel összefüggő konfliktusokra. A telep állapotát, az itt élők helyzetét jelzi, hogy több illegális lakó húzta meg magát a melléképületekben, ők jellemzően rokoni szálakkal kötődnek a tömb bérlőihez.

„Van itt egy öreg, egy kormos kamrája volt, mert az valamikor kigyulladt, és ö is megégett. De nem hagyta ott a kamrát. A huszonpár fokos hidegekben nekünk melegünk volt, de o" sem fázott abban a kamrában. Nem tudom, hogy élte túl. Csak o" volt egyedül. Se ajtó, se semmi. Most itt van a testvérénél, a legelső lakásban." (K6)

A változások egyrészt a település szociálisbérlakás-politikájához kapcsolhatók. A város időről időre kénytelen „beáldozni” bizonyos lakóterületeket: 
ahogy a korábbi évtizedben az előbb említett keleti tömb szociális bérlakásaiba költöztették a városszerte lakbértartozást felhalmozó családokat, úgy napjainkban a Marosi úti telep vált a városi bérlakás-politika áldozatává. Másrészt a beköltöző családokkal való mindennapi konfliktusok, a telep fizikai leromlása törvényszerűen vezetett a lakók közötti szelekciós mechanizmusok felerősödéséhez. Azok a szerencsések, akiknek lehetőségük nyílott rá, elköltöztek a telepről, ami csak tovább erősítette a társadalmi problémák koncentrációját. A Marosi úti lakások lecsúszása mindenki számára érzékelhető, a tömb egyértelműen megbélyegzett lakókörnyezet. A városban dolgozó szociális szakemberek is sarkosan fogalmaznak: „A legkezelhetetlenebbek, öntörvényüek. És azok kerültek jobbára oda, akiket a többi cigány kiutált a saját köreikból." Amikor a telep szóba kerül, van, aki az élhetetlen lakókörnyezetre, van, aki a szelekciós folyamatokra helyezi a hangsúlyt, de a város közvéleménye és a családokkal foglalkozó szakemberek abban egyetértenek, hogy a Marosi úti telep a többségi társadalomtól, a város egészétől élesen elkülönülő, társadalmon kívüli világ.

„Lassan alakult át roma gettóvá - mert kimondhatjuk, hogy azzá alakult, sajátos törvényekkel, sajátos szokásokkal. Voltak benne magyar családok is, ök elhagyták, lehet, hogy ebben közrejátszott szomszédság is. Aztán kiutalásoknál kinek kell, önkormányzat is úgy rakott bele embereket - magyar lakos nem kérte sokszor. Így kontraszelektív úton alakult ki. A '90-es évek elso" felében, '95-ig alakult ki, hogy csak romák." (korábbi családgondozó)

\section{A Marosi úton élő családok}

A város szemében a Marosi úti szociális bérlakások lakói nem egyszerüen szegények, hanem deviáns, máról holnapra élő, a többség számára veszélyes népesség. Ez egy olyan hely, ahova veszélyes kimenni, olyan emberek laknak itt, akikkel nem jó kapcsolatba kerülni. Ugyanakkor a Marosi úton a családok mind a háztartás szerkezetét, mind a megélhetés, boldogulás lehetőségeit tekintve igen különböző helyzetben vannak, azaz a társadalomstatisztikai adatok alapján és a város szemében egyaránt homogén gettó belülről vizsgálva erősen differenciált képet mutat (Small 2008). Az egyedülálló nyugdíjasoktól a többgenerációs, rokonokat befogadó sokszemélyes háztartásokig, a konszolidált, még gyermekeiket is támogatni tudó háztartásoktól a végletesen eladósodott, máról holnapra élő, kilakoltatás szélén álló családokig sokféle élethelyzetben levő család él együtt. A háztartásnagyság és a boldogulási lehetőségek között szoros, de nem minden esetben érvényes összefüggés mutatkozik. Megfigyeléseink szerint a háztartás nagyságát és anyagi stabilitását jelentős mértékben befolyásolja, hogy az adott család mióta él a Marosi úton, hogy honnan, milyen társadalmi környezetből érkezett, valamint hogy milyen kapcsolatokkal rendelkezik. 


\section{Stabil anyagi helyzetü családok}

Miközben a városban a telepet egyöntetűen a legszegényebbek között tartják számon, a háztartásokat vizsgálva kiderül, hogy az itt élő 14 háztartás közel fele anyagilag stabil helyzetűnek mondható. E háztartások közös jellemzője, hogy legalább egy tagjuk rendszeres jövedelemmel rendelkezik. A stabil háztartások nagyobb része egyazon rokonsági rendszerhez, nagycsaládhoz tartozik, ahol egy-egy háztartásban legfeljebb három fó él, másik részét olyan többgenerációs családok alkotják, ahol ugyan a lakás túlzsúfolt, hatan-nyolcan is élnek egy lakásban, de a háztartásban több kereső is van, és a legfiatalabb generáció közeli céljai között szerepel a telepről való elköltözés.

\section{Az őslakosok és rokonságuk}

A stabil háztartások jelentős részét azok alkotják, akik legkorábban érkeztek a telepre, évtizedek óta itt élnek, itt nőttek fel és kisebb kitérők után, családos emberként ide költöztek vissza. A telepen hét olyan háztartást találtunk, ahol legfeljebb hárman élnek egy háztartásban, ebből öt anyagilag stabilnak mondható. ők mindannyian a telep „őslakosai”; a két nagymamakorban lévő, idős özvegyasszony még a nyolcvanas évek elején költözött a telepre, évtizedek óta egymás közelében élnek. Egy-egy gyermekük évtizedekkel ezelőtt itt, a telepen ismerkedett meg házastársával és házasodott össze. Különbség a két család között, hogy míg a nem cigány asszony két gyereke a családalapítással elköltözött a telepről, addig a cigány család nyolc gyermekének fele a telepen maradt vagy több lakáscsere után visszatért ide - jelenleg négy lakást foglalnak el. A nem roma asszony egyedül él, de minden nap látogatja ôt a városban albérletben lakó, de az „öröklés miatt” ide bejelentett fia vagy unokája, a panelban élő gyerekek az asszony fáskamráját használják szerszámosnak. A cigány asszony az egyik fiával él, aki rendszeresen bevásárol nemcsak anyjának, de egy velük félig-meddig rokonságban levő másik idős nőnek is. A két háztartás alapvetően az idős asszonyok nyugdíjjövedelmének köszönhetően anyagilag stabil helyzetű.

A cigány asszony telepen élő gyermekeinek háztartásai ugyancsak stabilnak mondhatók, hiszen vagy rendszeres munkajövedelem, vagy nyugdíjszerü ellátás biztosítja a családok megélhetését. E családból a máig édesanyjával élő férfin kívül a második fiútestvér kisebb kitérőkkel, minőségi lakáscsere révén tért vissza a Marosi útra. Elvált, gyerekei családot alapítottak és elköltöztek, ő továbbra is itt él. A telepen ő az egyetlen, akinek több évtizede folyamatos munkaviszonya van. Számos kapcsolattal rendelkezik a városban, részben munkahelyének, részben korábbi aktív polgárőr tevékenységének köszönhetően. A telepen él a harmadik gyerek is, az egyetlen leány, aki már 16 évesen munkába állt. A helybeli, képzetlen asszonyok számára munkát biztosító nagy cégeknél dolgozott, a pamutfonónál majd a baromfifeldolgozóban, majd e cégek megszűnése után leszázalékolták. Férjével - akinek családja is itt él - a telepen ismerkedtek meg, jelenleg két nyugdíjból élnek. 
A telepen élő negyedik testvérnek már csak a családja, fiatal felesége és két gyermeke él a tömbben, ő maga válásuk után elköltözött. A fiatal nő tanyán született, 15 évesen jött férjhez a Marosi útra, ahol majd másfél évtizedig az anyósánál laktak. Hiába a hosszú évek együttélése, a távolságot megtartották és mindvégig külön konyhán maradtak. Amikor a telepen egy idős nő halálával megürült egy lakás, az asszony az önkormányzatnál ,járta ki”, hogy megkaphassák. Közben fiatal asszonyként - sok telepi társához hasonlóan - a baromfifeldolgozóban dolgozott. A családok anyagi „stabilitásának” viszonylagosságát jelzi, hogy az ő életükben is volt olyan időszak, amikor tetemes lakbérhátralékuk halmozódott fel. Amikor az asszony munkanélküli lett, a nyolc osztály befejezése érdekében kötelező esti iskolába járt, nem vették fel közmunkára sem, és a férje éppen ebben az időben hagyta el a családot. Hónapokig csak a közmüdíjakat tudták nagy nehézségek árán kifizetni, a lakbérre majdnem egy évig nem futotta. Mivel a feleség a lakásosztályon jelezte együttműködését és részletfizetési kérelemért folyamodott, nem lakoltatták ki őket. Idővel, mióta az asszonyt rendszeresen és folyamatosan alkalmazzák közmunkán utcai takarítóként és egykori férje is hozzájárul a gyerekek nevelési költségeihez, anyagi helyzetük stabilizálódott.

\section{Többgenerációs családok szétválás elött}

A stabil anyagi helyzetü háztartások közé tartozó további két háztartás nagyon hasonlít egymásra. Mindkét család a közeli cs-házas telepről került ide, de nem állnak egymással rokonságban. Jelentős és kiterjedt rokoni, ismeretségi kapcsolatrendszert ápolnak a helyi alkalmi munkákat szervező vállalkozókkal, így a család több tagja rendszeresen eljár dolgozni.

„Édesapám is kábelfektető vállalkozó volt, és oda jártunk, több éven keresztül oda jártunk, ilyen családi vállalkozás volt ez majdnem. Csak nem az a túl nyereséges volt. 14 éves koromban bejelentett munkahelyem volt a Közútipari Vállalat. Muszáj volt elmenni, mert segíteni kellett a szülóknek. Nem sokáig tartott az a munka, öt vagy hat hónapig, utána ilyen alkalmi munka. Utána volt baromfifeldolgozó. De az megszünt. És azóta ilyen alkalmi munkából élek." (K11)

Mindkét háztartásban három generáció él együtt, hatan, illetve nyolcan egy lakásban, igen szükös körülmények között. Különbség a két család között, hogy a középgeneráció, az alig húszéves fiatalok egyike a telepi „szokásoknak” megfelelően egy szomszéd lányt vett el feleségül, míg a másik háztartásban „idegen” került a családba.

A családok legnagyobb problémája a zsúfoltság: három generáció együttélése soha nem mentes a konfliktusoktól. Napjainkban a telepen élő fiatal párok önállósodásának egyetlen lehetséges útja, hogy az önkormányzat szociális bérlakást utal ki számukra. A biztos anyagi helyzet relatív voltát és a szegénység mértékét jelzi, hogy még a legstabilabb anyagi helyzetben levő családok sem engedhetik meg maguknak, hogy piaci árat fizessenek egy lakás bérletéért, esetleg önállóan vásároljanak vagy építsenek lakást. 


\section{Billenékeny anyagi helyzetü, néha megszoruló családok}

A fent említett két családhoz hasonlóan a billegő anyagi helyzetű háztartásokhoz sorolt négy háztartásból háromban több generáció hat-hét tagja él együtt, zsúfoltan. A negyedik háztartásba hivatalosan csak hárman vannak bejelentve, de az unokák a nyári szünetben és az alkalmi munkák miatt gyakran iskolai idöben is itt, a nagyszülőknél vannak.

„Órabérben dolgoznak [a gyerekek]. Be kell, hogy osszák - van, amikor megyek én is segíteni a gyerekeknek. A fiam 500 forintos órabérben dolgozik, a menyem 460 forintos órabérben. Van, amikor 15-16 óra hosszát ott vannak. Én fogom hordani óket [az unokákat iskolába], mert van, amikor hajnal kettókor már dolgoznak, és akkor nem lehet a gyerekeket úgy hagyni. Egyetlenegyszer volt olyan, hogy nem volt felügyelet, és mire odaértem, a kislány olyan beteg volt, hogy nem tudott lábra állni. Ennek a veszélynek nem teszem ki öket." (K6)

A négy háztartásból három csak néhány éve él ezekben a szociális bérlakásokban, előtte mindannyian évekig a város legalacsonyabb presztízsű lakóhelyein laktak, külterületi tanyákon, az azóta lebontott, laktanyából kialakított gettósodó keleti tömb bérlakásaiban vagy éveket töltöttek el a családok átmeneti otthonában.

Az egyik család helyzetét a zsúfoltságon túl betegségek is nehezítik: a nyolcvanas évek vége óta itt élo", napjainkra hétfősre duzzadt háztartásnak szinte nincs olyan tagja, akinek ne lenne valamilyen súlyos betegsége. Ez nemcsak anyagilag megterhelö, de az alkalmi munkák elvállalását is akadályozza. Bár ők a mezőgazdasági munkákat szervező vállalkozók kapcsolathálózatának részei, de betegségeikből következően rendszertelenebbül hívják őket dolgozni.

„Én nem bírok alkalmi munkát vállalni, a férjem még úgy se. Köszvényes, fekélyes lábak, vérnyomás. A fiam van, amikor hetente egy napot dolgozik ilyen alkalmi munkát - de még alkalmi munkát sem lehet vállalni, mert nincs. Paprikaszedés majd a jövő hónapban lesz, majd megpróbálom magam megerőltetni, gerincemet, áh, kizárt. Be van meszesedve a gerincem." (K6)

\section{Eladósodott, napi problémákkal küzdő családok, többnyire kilakoltatásra várva}

Terepmunkánk során három olyan háztartást találtunk a Marosi úti lakásokban, akiknek lakbér- és egyéb közüzemi tartozásaik annyira felhalmozódtak, hogy az önkormányzattól megkapták a kilakoltatási végzést. A telepen a lakók többsége időről időre fizetési nehézségekkel küzd. Általános stratégia, hogy legelőször a közműszámlákat, elsősorban a villanyt fizetik ki, és utoljára maradnak a város felé fizetendő díjak, köztük a lakbér. Mindez azért is alakult így, mert a lakók azt tapasztalták, hogy a lakbértartozásnak a legritkább esetben van következménye. A vagyonkezelő igyekszik méltányosan eljárni a családokkal, a konfliktusok, a kilakoltatás elkerülése érdekében részletfizetési lehetőséget biztosít 
számukra, és minden, a helyzet rendezésére irányuló törekvést értékel. Egyfajta informális alkuról van szó a város és a lakók között: a lakók viselik az elmaradt felújítás következményeit, részben saját forrásból igyekeznek azokat pótolni, cserébe a város méltányosan viselkedik a lakbérhátralékosokkal. Látogatásunkkor mindhárom kilakoltatással fenyegetett háztartásban szembetűnő volt a szegénység: a többi lakáshoz képest is sokkal kevesebb bútorzattal rendelkeztek, kopottabb környezetben éltek. Két háztartásban már a villanyt is kikapcsolták. A kilakoltatásra váró családok között rokoni kapcsolat van, de eladósodottságuk oka eltérő.

Az első két háztartás története pontosan jelzi a családok helyzetének kuszaságát, a folyamatos rögtönzéseket és a kényszerű helyzetekhez való igazodást, az adott pillanatban legjobbnak tűnő, hosszú távon kockázatos választásokat. Az egyik háztartás saját tulajdonú családi lakását a tartozások miatt már a nyolcvanas évek végén elárverezték. Az éppen önállósodást tervező fiataloknak a baromfifeldolgozóban kapott keresetből és a napszámból összeszedett havi bevételből ebben az időszakban még futotta albérletre, később azonban, a gyerekek születése után egyre gyakrabban szorultak a családok átmeneti otthonába. Bár ebben az intézményben akár éveket is el lehet tölteni, de egyszer eljön a pillanat, amikor legalább egy időre el kell hagyni azt. Az intézményből kikerülve előbb ismerősöknél vagy rokonoknál húzták meg magukat, így éltek egy ideig a Marosi úton is. Majd már három gyerekkel az egyik cs-házas telep következett, ahol hasonló sorsú rokonok fogadták be őket. Ebben az időszakban a férj egy alkalmi munka során súlyos balesetet szenvedett. Mire a három gyerekkel, 17 év várakozás után, hat évvel ezelőtt megkapták a Marosi úton a lakást, a férj balesetéből következően már munkaképtelen volt, a mai napig kezelésre szorul. Megérkezésük után röviddel lányuk összebarátkozott az udvarban egy fiúval, hamarosan átköltözött hozzájuk, majd vissza a szüleihez, ide-oda csapódva a két háztartás között.

„Nem csináltam semmit. Diszkóba jártam, csak a barátnőimmel csavarogtunk, ideoda. Akkor jobb volt. Volt az Ezerjó, Gomba, meg ilyesmi, meg ide-oda elcsavarogtunk. (...) Öt és fél éve vagyok együtt a férjemmel. 14 éves voltam, amikor összebarátkoztunk." (K9)

A kapcsolatból hamarosan gyerek született. Mivel a lány fiatalkorú volt, az anyja vállalta a gyámságot, s gyakorlatilag máig ő neveli az unokát. Az unoka jelenléte és a férj/nagyapa betegsége lehetetlenné teszi, hogy rendszeresen alkalmi munkát vállaljanak. Évek óta vannak tartozásaik az önkormányzat és a közműszolgáltatók felé. Az áramot már két éve kikapcsolták.

„Nem voltam itthon, akkor jött kilencezer forintom, szó nélkül kikapcsolták. Mire megjöttem, már nem volt villany. Visszakapcsolni hogyne, drága. Nem zavar, hogy nincs, hozzá vagyunk szokva. Volt tévénk is, meg minden. Van ilyen kis lámpám, azt azzal szoktam világitani. Szomszédba el szoktam menni a lányomékhoz tévézni." (K8)

Tavaly a szórványos alkalmi munkák jövedelmeiből arra még futotta, hogy az önkormányzat felé a lakbérhátralékot időről időre törlesszék, ezzel el tudták kerülni a kilakoltatást. Terepmunkánk évében, alkalmi munkák híján ezt már 
nem tudták megtenni. Közben a férj idős, beteg, ápolásra szoruló testvére is hozzájuk költözött. Mivel a családban hivatalosan már nincs kiskorú gyermek, nincs hova menniük. A családok átmeneti otthonába, amely többször menekülési lehetőséget kínált számukra, már nem térhetnek vissza. Az anyát az vigasztalja, hogy legalább az ugyancsak kilakoltatás előtt álló lánya tud majd élni ezzel a lehetőséggel.

Lánya olyan családba ment férjhez, amelyik már húsz éve itt él, s ahol az édesanya három fiúgyermeket nevelt fel. Korábban a felnőtt testvérek is itt laktak családjaikkal, innen költöztek tovább a közeli megyeszékhelyre. Elköltözésükkel vált lehetővé, hogy a fiatalabb fiú végre „birtokba vehesse” a lakást. Elbeszélésük szerint a család jövedelméből rendszeresen fizették a rezsiket, köztük a lakbért is, ezért érte őket váratlanul a több százezer forintos elmaradás miatti kilakoltatási végzés, azt mondják, hogy az adósságot a már elköltözött, de a lakásból ki nem jelentkezett egyik idősebb testvér hagyta maga után.

A harmadik kilakoltatás előtt álló család helyzete eltér az előzőktől. Alig három éve élnek itt, a lakásban már beköltözésük idején is ki volt kapcsolva az áram, amelyet azóta illegálisan használnak, a vízcsap sem működik a lakásban. A háztartásban a szülők mellett négy kamaszkorú fiú él, akik az elbeszélések szerint rendszeresen járnak alkalmi munkára, de abból a közös háztartásba nem sokat juttatnak. Az apa masszív italozása, folyamatos, napi rendszerességű randalírozása, amely gyakran az apa és a fiúk közötti verekedésbe torkollik, nyomasztja a családot és az egész lakóközösséget. Az apa már többször volt börtönben, a kutatás idején is arra vártak, hogy bevonuljon, abban reménykedtek, hogy így egy időre rendeződik a család élete.

\section{Az udvarban egymás között - közösségi kapcsolatok}

Az együttélés során különböző együttműködési formák alakultak ki a telepi családok között. A közösségi életről, szomszédsági kapcsolatokról való beszámolókat áthatja a Marosi út megbélyegzettségének tudata; ez egy olyan hely, ahonnan menekülni kell, amelyet itt kell hagyni, amely azonban egyfajta „sorsközösséget" is jelent a lakók számára.

A stabilabb megélhetéssel rendelkezők törekszenek arra, hogy távol tartsák magukat a közvetlen, személyes kapcsolatoktól, és hogy a meglevő érintkezéseket kifejezetten lakáson kívül tartsák. Számukra a jó viszony ugyanis automatikusan a kölcsönöket, szívességeket és az ebből következő konfliktusokat jelenti. Ugyanakkor még a stabil anyagi helyzetünek mondható családok sem engedhetik meg maguknak, hogy kölcsönözzenek, másokon segítsenek, hiszen ezek az apró segítségnyújtások is megingathatják saját háztartásuk biztonságát. Az ilyen szükös anyagi környezetben a közösségi - családi, rokonsági vagy szomszédsági - szolidaritás az egyéni boldogulás gátjává válhat. 
„Van, amikor pénzileg is szoktam [segiteni]. Mindig visszaadja. Ha van, akkor adok, ha nincs, akkor az utolsót nem adom oda. [Mással jóban van az udvarban?] Jaj, nem szeretek társalogni. Nem tudom miért, de nem. Mondjuk, így ide sem járok át nagyon, nem szeretek. Nem, mert utána az emberre úgy rászoknak, hogy nem győzi gyünni-menni. Én ezt nem szeretem. Ezek nagyon értenek ám mindent kérni." (K5)

A kialakult kapcsolatok egyik része a folyamatosan újratermelődő rokonsági viszonyokból fakad. A szűkös, korlátozott kapcsolati hálóval rendelkező fiatalok, akiknek az iskolából való kimaradás után szinte semmilyen kapcsolatuk nem marad a többségi társadalom intézményeivel és csoportjaival, előbb-utóbb a házból vagy az ide látogató rokonok közül választanak maguknak élettársat. A családok között gazdag rokonsági hálózat alakult ki, napi rendszerességgel járnak itt át egymáshoz testvérek, menyek, nászasszonyok. Az együtt töltött időn túl megjelennek a kölcsönös szívességek is, amelyek átsegítenek a mindennapi gondokon.

„Itt az egyik szomszédasszonynak elszakadoztak a zipzárak, zipzárosak voltak, akkor mondta, csináljam már meg neki. Szeretem csinálni, aztán megcsinálom neki gombosra, zipzárt kivettük belőle, gombokat raktunk rá. Ilyen dolgokat megcsinálok mind, valamivel kell foglalkozni, ha nem csinálok semmit, az olyan rossz. Ide hozzák mindig az anyagot. El ne menjek innen, mondják, mert akkor mi lesz velük. (...) Ha valami olyan van, jönnek, segitenek. Ne menjek boltba, hoznak szívesen, csak mondjam, hogy mit. Úgyhogy ebból kifolyólag nem panaszkodhatok rájuk. Csak ez a zajosság..." (K1)

A kívülállók arról beszélnek, hogy a Marosi úton lakó családok gyakran balhéznak és hangoskodnak. Az itt lakók is szívesen hangoztatják a többség által róluk kialakított képet, ugyanakkor minden család tudja, hogy a jó viszony fenntartása már csak a szomszédok közelsége, az összezártság miatt is szükséges. A zsúfoltság és a nyitott terek miatt a családok minden eseményt hallanak, de a bajban is számíthatnak egymásra.

A szegénységben élő családokat egymáshoz kötő, valamint a családon kívülre mutató, a többségi társadalom felé irányuló kapcsolati hálók jellegének és sürüségének nagyon fontos szerepe van (Messing, Molnár 2011). A telepen élők szinte csak a város más telepein lakó, hozzájuk hasonló anyagi, szociális helyzetű rokonaikkal állnak kapcsolatban, rendszeresen látogatják őket, továbbá a Marosi úti tömbben is időről időre feltűnnek a város más szegénytelepein élő rokonok. Az alapvetően az egymás iránti bizalmon, reciprocitáson, szolidaritáson alapuló összetartó kapcsolatok befelé zártak, homogének és a mindennapi túlélést, a biztonságot szolgálják. Ugyanakkor ezek a kapcsolatok mérséklik a szegénységből való kitörés esélyét, és erősen korlátozóak is lehetnek abban az esetben, ha a csoportszolidaritás legfőképp a társadalom foáramával való szembenálláson és ellenkezésen alapul. Ez a jelenség elsősorban a térbeli, társadalmi, etnikai kirekesztettségben, zárványokban élő közösségekre jellemző (Portes 1995; Putnam 2000). Az általunk vizsgált telepen is csak néhány családra jellemző, hogy a saját társadalmi csoporton átnyúló, civil szervezetekhez, intézményekhez füződő összekötő (bridging) vagy összekapcsoló (linking) (Putnam 2000) kapcsolatai lennének, amelyek a külső forrásokhoz való hozzájutást és a 
mobilitást szolgálnák. Csak néhány családnak van olyan külső „,rokoni” kapcsolata, amelyen keresztül munkalehetőségekhez jut. Ezekben az esetekben a tényleges vérségi rokonság jelentősége másodlagos, hiszen a kapcsolatot alapvetően a kölcsönös érdekek tartják fenn: az a rokon, akit be lehet szervezni alkalmi munkára és aki megbízhatóan dolgozik (Virág 2008). A más, jobb helyzetű, különböző erőforrásokkal rendelkező városi csoportokhoz kötődő rokoni vagy baráti viszonyokon túl jelentős szerepe lenne az intézményekkel ápolt kapcsolatoknak is. Az, hogy ki milyen kapcsolatot alakít ki a szociális osztály, a lakásosztály, vagy a családok átmeneti otthonának vezetőjével, a kisebbségi önkormányzat képviselőivel, jelentős mértékben befolyásolhatja lakhatási helyzetét. Ugyan a telepen élők közül néhányan büszkélkedtek ilyen jellegü kapcsolatokkal, csak elvétve hallottunk sikeres történeteket ezek tényleges müködéséről.

\section{Összegzés}

Tanulmányunkban egy szociálisbérlakás-tömb lakóinak történetein keresztül bemutattuk, hogyan alakult egy alföldi város peremén elhelyezkedő mikrovilág szociális és etnikai összetétele és ezzel párhuzamosan e telep megítélése az elmúlt évtizedekben. Abban, hogy a város e szociálisbérlakás-tömbje napjainkra nemcsak térben, hanem társadalmilag is peremhelyzetbe került, egyfelől a városban zajló telepfelszámolások és az ehhez köthető költöztetések, a város bérlakás-politikája és a szelektív lakáskiutalási rendszer, másfelől a marginalizálódó tömbben elinduló szelekciós folyamatok egyaránt szerepet játszottak. A társadalmi peremhelyzet együtt jár a telep etnicizálásával, stigmatizációjával és gyakran kriminalizálásával, azaz a telep a város lakói és intézményei számára napjainkra „roma gettóvá” alakult át. E kép szerint a telepen kizárólag olyan cigány családok élnek, akiknek a megélhetése segélyeken és informális, illetve illegális jövedelmeken alapul. A családok háztartásszerkezetét és megélhetési lehetőségeit vizsgálva ezzel szemben azt tapasztaltuk, hogy a város és lakói által megbélyegzett telepen élő családok helyzete rendkívül differenciált: a stabil, kiszámítható jövedelmekkel rendelkező háztartásoktól a máról holnapra élo", lakbértartozást felhalmozó, kilakoltatás előtt álló családokig széles skálán mozog. A stabil hátterűnek mondható családokhoz a vizsgált tömbben az „őslakosok” és a kapcsolati hálójuk révén viszonylagos anyagi biztonságra szert tett családok tartoznak, míg a leginkább instabil helyzetben a legutóbb - többségében a város más, alacsony státuszú részeiből, tanyákról, a családok átmenti otthonából - beköltöző családok vannak. Azonban még a legstabilabb anyagi helyzetben levő családok sem engedhetik meg maguknak, hogy önálló lakást vásároljanak vagy piaci alapon béreljenek, a telepről való térbeli és az ezzel együtt járó társadalmi elmozdulás szinte lehetetlenné vált az itt élők számára. A hosszú évek, évtizedek óta egymás mellett élő családok között szoros, gyakran 
rokoni kapcsolatok szövődtek, amelyek segítik a mindennapok túlélését, de be is zárják a családokat e kapcsolatrendszerbe. A telep marginalizációjával párhuzamosan egyre meghatározóbbá váltak a túlélést segítő, megkötő kapcsolatok és koptak el a más társadalmi csoportok, a többségi intézmények felé mutató kötődések, amelyek elősegíthetnék a térbeli és társadalmi mobilitást.

\section{Jegyzetek}

1 Kutatásunkat 2012 nyarán, a Társadalomelméleti Kollégium szervezésében végeztük az Új Széchenyi Terv TÁMOP-4.2.2/B-10/1-2010-0023 projekt keretein belül. Egyhetes terepmunkánk során közel 70 interjú készült bérlakásban és szegregált lakókörnyezetben élőkkel, valamint a városi lakás- és szociálpolitika szereplőivel. Tanulmányunkban saját interjúinkon túl a közösen gyüjtött információkra is támaszkodunk, melyekért köszönet illeti a készítőket: Bihari Györgyöt, Gimes Dórit, Ivanics Zsófiát, Kecskeméti Zoltánt, Kovács Veronikát, La-Torre Krisztinát, Müller Kingát, Neumann Pétert, Pintér Ádámot, Tabajdi Esztert és Vigvári Andrást. A kutatás részletes eredményei itt olvashatók: Kemény V. (szerk.): Kisváros peremén. http://tek.bke.hu/files/Kisvaros_peremen_szocep_kutato_kiadvany.pdf

2 Cs- vagy csökkentett értékủ lakások. A hetvenes években megindult állami akció keretében általában szoba-konyhás, komfort nélküli házakat építettek a telepekről beköltöztetett romák számára.

\section{Irodalom}

Ambrus P. (1988): A Dzsumbuj: egy telep élete. Magvető Kiadó, Budapest

Berescu, C., Petrović, M., Teller, N. (2013): Housing exclusion of the Roma. Living in the egde. In: Hegedüs J., Lux, M., Teller, N. (eds.): Social housing in transition countries. Routledge, New York, 98-113.

Berey K. (1990): A szociális követelményeknek meg nem felelő telepek felszámolása. In: Berey K., Horváth Á. (szerk.): Esély nélkül. Vita Kiadó, Budapest, 5-72.

Domokos V., Herczeg B. (2010): Terra incognita: magyarországi szegény- és cigánytelepek felmérése - első eredmények. Szociológiai Szemle, 3., 82-99.

Éves jelentés a lakhatási szegénységról 2011. Városkutatás Kft., Habitat for Humanity, Budapest, 2012

Fehér K., Müller K., Tabajdi E. (2013): Lakhatási kérdések egy alföldi kisvárosban In: Kemény V. (szerk.): Kisváros peremén. Társadalomelméleti Kollégium, Budapest, 10-38. http://tek.bke.hu/files/Kisvaros_peremen_szocep_kutato_kiadvany.pdf

Havas G. (1999): A kistelepülések és a romák. In: Glatz F. (szerk.): A cigányok Magyarországon. Magyar Tudományos Akadémia, Budapest, 163-203.

Hegedüs J., Eszenyi O., Somogyi E., Teller N. (2009): Lakhatási szükségletek Magyarországon. http://www.habitat.hu/hu/tudaskozpont/publikacio/2/

Hegedüs J., Tosics I. (1998): A közép-kelet-európai lakásrendszerek átalakulása. Szociológiai Szemle, 2., 5-32.

Janky B., Kemény I. (2004): Települési és lakásviszonyok. Beszélo", 4., 96-110.

Kemény I. (1976): A magyarországi cigányok helyzete. In: Kemény I. (szerk.): Beszámoló a magyarországi cigányok helyzetével foglalkozó, 1971-ben végzett kutatásról. MTA Szociológiai Kutató Intézet, Budapest, 7-63. 
Ladányi J. (1989): A lakásrendszer változásai és a cigány népesség térbeni elhelyezkedésének alakulása Budapesten. Valóság, 6., 73-89.

Ladányi J. (2000): Az üldözésről gondoskodó önkormányzatok. Kritika, 9., 11-14.

Ladányi J., Szelényi I. (2004): A kirekesztettség változó formái. Napvilág Kiadó, Budapest

Lengyel G. (2006): Cigánytelepek egykor és ma. In: Kállai E., Törzsök E. (szerk.): Átszervezések kora. Cigánynak lenni Magyarországon. Jelentés 2002-2006. Európai Összehasonlító Kisebbségkutatások Közalapítvány, Budapest, 56-91.

Nagy E., Timár J. (2007): A középvárosi dzsentrifikáció társadalmi hatásai a posztszocialista Magyarországon. In: Enyedi Gy. (szerk.): A történelmi városközpontok átalakulásának társadalmi hatásai. MTA Társadalomkutató Központ, Budapest, 293-319.

Messing V., Molnár E. (2011): Bezáródó kapcsolati hálók: szegény roma háztartások kapcsolati jellemzői. Esély, 5., 47-74.

Portes, A. (1995): Children of immigrants: Segmented assimilation and its determinants. In: Portes, A. (ed.): The economic sociology of immigration. Essays on networks, ethnicity, and entrepreneurship. Russel Sage Fundation, New York, 248-279.

Putnam, R. (2000): Bowling alone. The collapse and revival of American community. Simon \& Schuster, New York

Small, M. L. (2008): Four reasons to abandon the idea of the ghetto. http://home.uchicago.edu/ mariosmall/documents/Small_CC_2008.pdf

Solt O. (1998): A hetvenes évek budapesti szegényei. In: Méltóságot mindenkinek. Összegyüjtött írások. Beszélö, Budapest, 242-288.

Teller N. (2011): Adaptációs csapdák. Hipotézisek a romák lakásmobilitásáról a 2010-es roma adatfelvétel lakásváltoztatási kérdéseire adott válaszok és a korábbi cigányfelvételek lakásmobilitási adatai alapján. In: Kurucz E. (szerk.): Roma kutatások, 2010 - élethelyzetek a társadalom peremén. Nemzeti Család- és Szociálpolitikai Intézet, Budapest, 203-218.

Virág T. (2006). A gettósodó térség. Szociológiai Szemle, 1., 60-76.

Virág T. (2008): Változó gazdasági-társadalmi kapcsolatok egy cigányok lakta faluban. Szociológiai Szemle, 1., 41-59.

Wacquant, L. (2007): Territorial stigmatization in the age of advanced marginality. Thesis Eleven, 1., 166-177. 